\title{
Studi Perkembangan Pariwisata Dan Pengaruhnya Pada Lingkungan Fisik Di Pantai Balangan, Desa Ungasan, Jimbaran
}

Yulien Prastika a, 1, I Nyoman Sunarta a, 2

1yulienprastika@gmail.com, 2 nyoman_sunarta@unud.ac.id

a Program Studi S1 Destinasi Pariwisata, Fakultas Pariwisata,Universitas Udayana, Jl. Dr. R. Goris, Denpasar, Bali 80232 Indonesia

\begin{abstract}
The background of this research is Balangan beach in the town of Jimbaran that has problems such as facilities development in the coastal setback and the trash accumulating in the coastal setback after tourism development in the area.

Based on the above research that revealed two problems, namely how was the tourism development in Balangan beach? And how was the effect of tourism development in physical environment in Balangan beach? To express the above problem this research using primary data source, while type of data used is the qualitative data and quantitative data. The method of data collection through observation and interviews. With data analysis using descriptive qualitative method.

The results of the research that the tourism development in Balangan beach on the development phase. And the effect of tourism development in physical environment were the accommodation and restaurant increase, the attraction increase with many activity, the path heading towards the beach was repaired, the water stock the source comes from a well in Cengiling village, and the garbage dump effect was bad.
\end{abstract}

Keywords : tourism development, effect, physical environment.

\section{PENDAHULUAN}

Saat ini pariwisata merupakan salah satu sektor unggulan bagi Indonesia selain sector migas maupun non-migas yang digunakan untuk meningkatkan devisa negara. Selain menambah devisa negara, sector pariwisata juga mampu membuat masyarakat mngalami metamorphose. Hal tersebut dikarenakan pariwisata merupakan kegiatan yang menyentuh dan melibatkan masyarakat yang kemudian membawa perubahan terhadap masyarakat setempat.

Adanya perkembangan pariwisata akan memberikan keuntungan, terlebih pada aspek ekonomi. Selain itu juga membangkitkan pendapatan membuka lapangan pekerjaan, memperbaiki kesejahteraan masyarakat, menaikan penghasilan dari pajak, serta sebagai multiplier effect atau pengganda bagi kegiatan kegiatan lainnya (Butler dan Douglas, 2003). Pariwisata juga menyentuh aspek kehidupan masyarakat seperti politik serta keamanan, Perkembangan pariwisata juga akan mempengaruhi suatu kawasan pariwisata terutama pada kondisi lingkungan tepatnya pada fisiknya. Perubahan tersebut biasanya terlihat adanya alih fungsi lahan, terjadi pembangunan bagi sarana dan prasarana pariwisata, bahkan akan adanya sampah yang berserakan disepanjang pantai yang diakibatkan oleh kunjungan wisatawan (Lestyono, 2010)

Maka dari itu wilayah di Indonesia berbondong - bondong untuk meningkatkan pariwisatanya. Salah satu wilayah yang mengalami perubahan dari adanya kegiatan pariwisata yaitu Bali.

Bali merupakan pulau kecil yang letaknya berada disebelah timur dari pulau Jawa. Pariwisata Bali terkenal melalui daya tarik wisatanya, baik alam, budaya, dan buatannya. Banyak wisatawan baik mancanegara atau nusantara ke Bali untuk berlibur maupun keluar dari rutinitasnya sehari hari. Daya tarik yang sering dikunjungi wisatawan yakni seperti Pantai Kuta, Pantai Sanur, Desa Panglipuran, Ubud, serta Garuda Wisnu Kencana. Meskipun begitu terdapat salah satu daya tarik wisata yang biasa dikunjungi oleh wisatawan yaitu Pantai Balangan. Pantai Balangan ini terletak di Desa Ungasan, Kelurahan Jimbaran, Kecamatan Kuta Selatan.

Adanya perkembangan pariwisata yang terjadi, Pantai Balangan banyak dikunjungi oleh wisatawan khususnya wisatawan mancanegara. Wisatawan yang berkunjung banyak melakukan kegiatan seperti surfing. Maka dari itu banyak masyarakat lokalnya yang ikut berpartisi dalam kegiatan yang ada di Pantai Balangan seperti membuat penginapan, warung makan, ataupun 
penjaga pintu masuk. Namun, masyarakat lokal yang ikut berpartisipasi tidak memperhatikan aturan. Hal tersebut dilihat dari bangunan yang berada di pesisir pantai. Bahkan sampah sampah yang ada dibuang di sempadan pantai. Dan pembangunan sempadan pantai yang seharusnya dibangun $100 \mathrm{~m}$ dari bibir pantai saat pasang namun di Pantai Balangan sempadan ini dibangun hanya beberapa meter saat air laut pasang.

Berdasarkan latar belakang di atas maka dapat dirumuskan permasalahannya yaitu bagaimana perkembangan pariwisata dan pengaruh perkembangan pariwisata terhadap lingkungan fisik di Pantai Balangan. Desa Ungasan, Jimbaran. Tujuan dari penulisan artikel ini adalah untuk mengetahui sejauh mana perkembangan pariwisata yang terjadi di Pantai Balangan serta mengetahui pengaruh dari adanya perkembangan pariwisata terhadap lingkungan fisik di Pantai Balangan.

\section{KEPUSTAKAAN}

Perubahan yang terjadi dari adanya perkembangan pariwisata terhadap lingkungan dapat berupa perubahan yang positif maupun perubahan yang negatif, seperti terjadinya pembangunan dan krisis air. Hal tersebut dapat dibuktikan dari penelitian sebelumnya yang berjudul "Dampak Perkembangan Usaha Akomodasi Terhadap Sumber Daya Air di Kecamatan Utara Kabupaten Badung Bali". Hasil yang ditunjukkan dalam penelitian ini yaitu terjadinya perubahan yang ditimbulkan dari perkembangan pariwisata khususnya akomodasi pariwisata terhadap penutupan lahan sehingga berakibat pada meningkatnya nilai koefisiensi aliran serta berdampak negative bagi potensi sumber daya air baik secara kuantitas dan kualitas (Sunarta, 2014).

Penelitian selanjutnya yang juga dilaksanakan oleh Sunarta (2015) dengan judul "Study on the Development of Water Crisis in Bali Island in 2009 and 2013". Hasil dari penelitian tersebut yakni terjadinya krisis air di Bali ditentukan oleh jumlah permintaan dan penawaran terhadap air. Pada tahun 2009, Bali mengalami kekurangan air khusunya lima dari sembilan kabupaten atau kota. Sedangkan pada tahun 2013 terjadi peningkatan, yaitu delapan dari sembilan kabupaten atau kota mengalami krisis air.
Dalam artikel studi perkembangan dan pengaruhnya pada lingkungan fisik di Pantai Balangan, Desa Ungasan, Jimbaran menggunakan beberapa konsep serta teori yang kemudian dipergunakan sebagai acuan dalam menjawab rumusan masalah yang telah ditetapkan. Konsep yang digunakan diantaranya:

\section{Konsep Pengaruh}

Pengaruh merupakan suatu daya yang menimbulkan suatu hal, sehingga menimbulkan atau mengubah ke sesuatu yang lain serta mengikuti maupun tunduk karena kuasa atau kekuasaan (Poerwadaminta, 2002).

Pada penelitian ini pengaruh yaitu perubahan yang ditimbulkan dari adanya perkembangan pariwisata terhadap lingkungan fisik di Pantai Balangan.

\section{Konsep Perkembangan}

Perkembangan adalah perubahan perubahan yang sifatnya progresif (maju) yang terjadi pada diri organisme terhadap pola pola yang memungkinkan terjadinya perubahan pada fungsi - fungsi baru (Moh. Surya dalam Gunarsa, 2016).

Perkembangan dibutuhkan dalam suatu daerah dikarenakan dapat meningkatkan fungsi serta perannya terhadap penataan kehidupan sosial, ekonomi, budaya, pendidikan, serta kesejahteraan (Muliadi dalam Gunarsa, 2016).

\section{Konsep Pariwisata}

Menurut Undang - Undang Republik Indonesia No. 10 Tahun 2009 tentang Kepariwisataan, Pariwisata merupakan berbagai macam kegiatan wisata yang didalamnya didukung oleh berbagai fasilitas fasilitas serta layanan - layanan yang telah disediakan oleh masyarakat, pengusaha, dan pemerintah daerah.

Sedangkan definisi lain tentang pengertian pariwisata dikemukakan oleh Spillane (dalam Susilo, 2015) yang mendefinisikan bahwa Pariwisata adalah kegiatan perjalanan dari satu tempat ke tempat yang lainnya serta sifatnya sementara, dan kegiatan perjalanan dilakukan oleh perseorangan maupun kelompok untuk mencari keserasian dan kebahagiaan dengan lingkungan hidup baik dalam dimensi sosial, budaya, alam, dan ilmu. 


\section{Konsep Lingkungan Fisik}

Lingkungan fisik merupakan segala sesuatu yang berada disekitar manusia yang sifatnya tidak bernyawa, contoh air, kelembapan udara, tanah, suhu, angin, rumah, serta benda mati lainnya (Faizun, 2009). Sedangkan lingkungan fisik pada perkembangan pariwisata yang dimaksud yaitu infrastruktur. Infrasturktur ini berkaitan dengan sarana dan prasarana untuk menunjang kegiatan pariwisata (Faizun, 2009).

Sarana pariwisata merupakan fasilitas yang diperlukan di suatu tujuan wisata yang kemudian digunakan untuk memenuhi kebutuhan wisatawan yang berkunjung (Suwantoro dalam Batafor, 2016). Sarana pariwisata yang dimaksud yaitu hotel, atraksi wisata, marina, gedung pertunjukan, angkutan wisata, restaurant, bar, tempat olahraga, dan rekreasi, serta toko cindramata (Suwena, 2010).

Prasarana pariwisata merupakan semua jenis fasilitas yang diharapkan dapat memperlancar proses perekonomian baik itu sumber daya alam maupun manusiayang dapat memenuhi kebutuahn wisatawan (Suwantoro dalam Batafor, 2016). Prasarana pariwisata ini yaitu jalan, persediaan air bersih, pembangkit tenaga listrik, pengelolaan limbah, tempat pembuangan sampah, bandara, pelabuhan, telefon, dan stasiun kereta api (Suwena , 2010). Konsep ini kemudian digunakan untuk menganalisis terkait dengan pengaruh perkembangan pariwisata terhadap lingkungan fisik di Pantai Balangan.

\section{Teori Tourism Area Life Cycle}

Teori yang dikembangkan oleh Butler (1980) ini dipergunakan untuk melihat perkembangan suatu daerah wisata yang dikenal sebagai Destination Area Life Cycle. Dalam teori ini terdapat 7 tahap atau fase, yaitu:

a. Exploration (Penemuan) : sebuah area wisata yang baru ditemukan, dikunjungi oleh wisatawan dalam jumlah sedikit, interaksi antara wisatawan dengan masyarakat lokal masih tinggi, fasilitas wisata masih sedikit.

b. Involvement (Keterlibatan) : jumlah kunjungan wisatawan ada peningkatan, masyarakat lokal mulai menyediakan fasilitas - fasilitas wisata, interaksi masyarakat lokal dengan wisatawan masih tinggi, adanya promosi yang dilakukan, serta ada perubahan pola - pola sosial masyarakat.

c. Development (Pembangunan) : investasi dari luar mulai masuk, promosi semakin intensif dilakukan, fasilitas lokal digantikan dengan fasilitas - fasilitas yang berstandar internasional, atraksi buatan mulai dikembangkan, tenaga kerja asing mulai masuk untuk mendukung industri pariwisata.

d. Consolidation (Konsolidasi) : jumlah kunjungan wisatawan tetap naik meskipun tidak signifikan, promosi lebih sering dilakukan, fasilitas wisata dibangun dan diperbaiki untuk ditingkatkan standartnya.

e. Stagnation (Stagnasi) : kunjungan wisatawan telah berada pada angka tertinggi dan bersifat tetap, wisatawan yang berkunjung hanya wisatawan repeater yang mana mereka memiliki alasan tersendiri kenapa mengunjungi daya tarik wisata atau destinasi tersebut.

f. Decline (Penurunan) : fasilitas wisata beralih fungsi untuk kegiatan lainnya, wisatawan sudah jenuh dengan atraksi yang ada.

g. Rejuvenation (Peremajaan) : adanya inovasi dalam pengembangan produk, menggali dan memanfaatkan sumber daya alam dan budaya yang belum dimanfaatkan.

Sehingga teori ini kemudian digunakan dalam membantu analisis permasalahan terkait dengan perkembangan pariwisata yang terjadi di Pantai Balangan.

\section{METODE PENELITIAN}

Lokasi dari penelitian ini berada di Pantai Balangan, Desa Ungasan, Jimbaran. Jenis data yang digunakan dalam penelitian ini yaitu data kualitatif yang berupa perkembangan pariwisata yang terkait dengan fasilitas pariwisata, atraksi wisata, dan interaksi masyarakat dengan wisatawan serta pengaruh perkembangan pariwisata terhadap lingkungan fisik yang terkait dengan sarana dan prasaran pariwisata. Sedangkan data kuantitatifnya berupa kunjungan wisatawan.

Sumber data yang digunakan adalah data primer, yang terkait mengenai perkembangan pariwisata serta pengaruhnya terhadap lingkungan fisik di Pantai Balangan yang datanya didapat dari hasil observasi dan wawancara dengan masyarakat yang ikut 
berpartisipasi dalam kegiatan kepariwisataan di Pantai Balangan. Teknik pengumpulan data dilakukan dengan observasi ke lapangan untuk mlihat pengaruh dari adanya perkembangan pariwisata di Pantai Balangan, wawancara dengan informan yakni masyarakat yang ikut berpartisipasi dalam kegiatan kepariwisataan di Pantai Balangan.

Teknik analisis data dilakukan dengan deskriptif kualitatif yaitu cara yang menekankan pada penggalian informasi yang kemudian hasilnya digambarkan dalam bentuk kata atau kalimat yang kemudian penyusunannya dilakukan secara teratur (sistematis) serta akurat mengenai fakta yang ada sehngga hasil terkait dengan perkembangan pariwisata dan pengaruhnya pada lingkungan fisik di Pantai Balangan dapat dipaparkan dengan baik tolak ukurnya.

\section{HASIL DAN PEMBAHASAN}

Pantai Balangan merupakan pantai yang terletak di wilayah Desa Ungasan, Kelurahan Jimbaran, Kecamatan Kuta Selatan. Jarak yang dibutuhkan dari Denpasar sekitar $25 \mathrm{~km}$ atau dapat ditempuh dalam waktu 60 menit, sedangkan dari Bandara Internasional Ngurah Rai sekitar $17 \mathrm{~km}$ atau dapat ditempuh dalam 45 menit. Pantai Balangan memiliki akses yang cukup mudah dikarenakan kondisi jalan yang cukup baik sehingga dapat diakses oleh kendaraan baik sepeda motor maupun mobil. Pantai ini juga memiliki pasir putih dengan ombak yang cukup besar dan memiliki air laut berwarna biru serta memiliki bebatuan yang dapat dilihat saat air sedang surut.

\subsection{Perkembangan Pariwisata}

Perkembangan pariwisata di Pantai Balangan dilihat dalam waktu 5 tahun sekali dikarenakan bila dilihat dalam kurun satu tahun-an belum terlihat perubahan yang terjadi secara besar. Perkembangan di Pantai Balangan dilihat dari aspek kunjungan wisatawan, fasilitas pariwisata, atraksi wisata, dan partisipasi masyarakat. Hal tersebut mengacu pada Teori Area Life Cycle yang memiliki sekitar tujuh indikator. Namun yang sesuai dengan Pantai Balangan hanya empat dari tujuh indikator.

\section{Kunjungan Wisatawan}

Perkembangan pariwisata di Pantai Balangan bila dilihat dari kunjungan wisatawan dimulai pada tahun 2006, yang saat itu kunjungan wisatawannya sekitar sebanyak 3.840 orang dengan didominasi oleh orang lokal. Sedangkan pada tahun 2011 kunjungan wisatawan diperkirakan sebanyak 38.400 orang dan masih didominasi oleh orang lokal. Dan pada tahun 2016, jumlah kunjungan wisatawan kurang lebih sebanyak 112.800 orang dan sudah didominasi oleh orang mancanegara.

Dari penjelasan diatas dapat diketahui kunjungan wisatawan bila dilihat dalam waktu 5 tahun sekali mengalami kenaikan. Dari tahun 2006-2011 pertumbuhannya sebanyak 34.560 orang dan pada tahun 2011-2016 pertumbuhannya sebanyak 74.400 orang.

\section{Fasilitas Pariwisata}

Fasilitas pariwisata merupakan aspek yang penting karena digunakan untuk menunjang kegiatan pariwisata, begitupun di Pantai Balangan. Fasilitas pariwisata di Pantai Balangan pada tahun 2006 hanya terdapat 2 bangunan, sedangkan tahun 2011 jumlahnya sebanyak 21, dan di tahun 2016 jumlah fasilitas yang ada menjadi sebanyak 27 buah. Fasilitas ini dalam jangka waktu setiap 5 tahun sekali mengalami kenaikan. Pertumbuhan fasilitas pariwisata di Pantai Balangan dari tahun 20062011 sebanyak 19 buah dan dari tahun 20112016 hanya sebanyak 5 buah.

Fasilitas - fasilitas ini meliputi akomodasi yang berupa hostel dan penyewaan kamar, restaurant atau warung makan serta café, tempat penyewaan sepeda motor, tempat penyewaan papan surfing, tempat penyewaan payung pantai, tempat sampah, tempat parkir, serta toilet.

\section{Atraksi Wisata}

Atraksi wisata sangat penting karena hal ini yang akan memikat wisatawan untuk datang berkunjung ke suatu daya tarik wisata. Atraksi wisata di Pantai Balangan di tahun 2006 hanyalah pantai itu sendiri, namun di tahun 2011 atraksi yang juga memikat wisatawan yaitu tebing yang ada di Pantai Balangan. Sedangkan di tahun 2016 tidak ada atraksi lain yang bertambah. Namun dalam atraksi - atraksi tersebut wisatawan dapat melakukan berbagai 
kegiatan, yaitu surfing, sunbathing, sunset, dan fishing. Dan di tebing wisatawan dapat melakukan sesi berfoto dengan latar belakang laut. Bahkan tebing ini sering digunkan untuk foto pre-wedding bagi wisatawan mancanegara.

\section{Partisipasi Masyarakat}

Bntuk partisipasi masyarakat dalam mengembangkan pariwisata di Pantai Balangan yaitu dengan menjadi penyedia fasilitas bagi kegiatan wisatawan, seperti mendirikan akomodasi, toilet, maupun fasilitas lainnya. Selain menjadi penyedia fasilitas pariwisata di Pantai Balangan, masyarakatnya juga ada yang menjadi pekerja di fasilitas - fasilitas yang ada. Meskipun begitu partisipasi ini tidak hanya dilakukan oleh masyarakat Desa Ungasan itu sendiri, melainkan orang dari luar juga ikut berpartisipasi meskipun itu hanya sebagai pekerja.

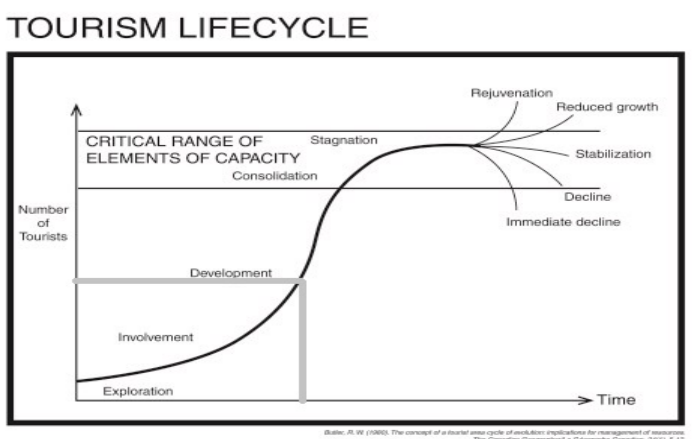

Gambar Tourism Area Life Cycle

Sumber: cred.ext.wvu.edu.jpg

Berdasarkan teori Area Life Cycle milik Butler tahun 1980, perkembangan Pantai Balangan berada pada tahap pembangunan (development). Hal ini ditandai dengan:

a. Kunjungan wisatawan yang selalu meningkat dalam kurun waktu 5 tahun sekali.

b. Fasilitas pariwisata yang selalu meningkat, yang awalnya hanya 2 buah menjadi 21 buah dan yang terakhir menjadi 27 buah.

c. Bertambahnya atraksi wisata, yang awalnya hanya pantai lalu bertambahnya tebing, dengan banyak kegiatan wisata yang dapat dilakukan.

d. Partisipasi masyarakat dilakukan dengan menjadi penyedia fasilitas pariwisata.

\subsection{Pengaruh Perkembangan Pariwisata Pada Lingkungan Fisik}

Pengaruh perkembangan pariwisata terhadap lingkungan fisik di Pantai Balangan dilihat dari dua aspek, yaitu aspek sarana pariwisata dan aspek prasarana pariwisata.

\section{Sarana Pariwisata}

Sarana pariwisata dilihat dari aspek akomodasi dan restaurant atau warung makan serta atraksi wisata. Dalam akomodasi, pengaruh dari perkembangan pariwisata yaitu saat ini ada 2 akomodasi yang satu berupa hostel dan yang lainnya berupa penyewaan kamar.

Pengaruh dari perkembangan pariwisata pada restaurant atau warung makan yaitu saat ini di Pantai Balangan terdapat 21 buah restaurant atau warung makan baik itu yang menggunakan bangunan permanen dan semipermanen.

Pengaruh perkembangan pariwisata pada atraksi wisata yaitu dulunya wisatwan hanya melht pantai saja dengan kegiatan berfoto namun saat ini tebing yang ada juga dijadikan sebagai atraksi wisata dengan kegiatannya berfoto. Dan kegiatan foto ini bukan foto biasa melainkan untuk foto pre-wedding bagi wisatawan mancanegara khususnya. Selain kegiatan berfoto, wisatawan juga dapat melakukan kegiatan melihat matahari terbenam (sunset), berjemur (sunbathing), memancing (fishing), dan (surfing).

\section{Prasarana Pariwisata}

Prasarana pariwisata dilihat dari aspek jalan, persediaan air, dan tempat pembuangan sampah. Pengaruh perkembangan pariwisata pada jalan yaitu jalannya bertambah menjadi lebih baik karena jalan menuju pantai sudah dibuatkan tangga, sedangkan jalan yang dari tempat pembelian karcis menuju tempat parkir sudah di paping.

Sedangkan pengaruh perkembangan pariwisata pada persediaan air yaitu persediaan air yang ada di Pantai Balangan tidak di dapatkan dari Perusahaan Daerah Air Minum (PDAM) melainkan mengambil dari sumur di Desa Cengiling. Sehingga air - air tersebut diangkut menggunakan tangki penampung air yang selanjutnya dimasukkan ke penampungan air yang letaknya berada di dekat fasilitas - fasilitas di Pantai Balangan. 
Pengaruh perkembangan pariwisata pada tempat pembuangan sampah yaitu cukup negatif karena di Pantai Balangan tidak memiliki tempat pembuangan sampah yang memadai baik untuk sampah organic maupun non-organik. Sehingga sampah - sampah yang dibuat oleh wisatawan atau sampah yang berasal dari laut saat pasang dibuang di sempadan pantai atau dibakar.

\section{PENUTUP}

\subsection{Simpulan}

Dari hasil pembahasan yang telah diuraikan diatas, maka dapat diambil kesimpulan yaitu:

1. Perkembangan pariwisata di Pantai Balangan berada pada tahap pembangunan (development). Hal tersebut berdasarkan dari 4 aspek yang telah ditentukan, yaitu kunjungan wisatwan yang selalu meningkat dalam kurun waktu 5 tahun sekali. Fasilitas pariwisata bertambah yang awalnya hanya 2 menjadi 27 buah baik akomodasi, restaurant atau warung makan, penyewaan papan surfing, penyewaan payung pantai, toilet, serta penyewaan sepeda motor. Atraksi wisata bertambah dari pantai lalu ada tebing dengan berbagai kegiatan. Dan partisipasi masyarakat yaitu dengan menjadi penyedia fasilitas pariwisata yang dibutuhkan bagi wisatawan.

2. Pengaruh perkembangan pariwisata pada lingkungan fisik dilihat dalam aspek sarana pariwisata dan prasarana pariwisata. Sarana pariwisata yang terkait dengan akomodasi dan restauran atau warung makan serta atraksi wisata. Prasarana pariwisata terkait dengan jalan, persediaan air, dan tempat pembuangan sampah. Dan pengaruh perkembangan pariwisata pada sarana pariwisata yaitu akomodasi di Pantai balangan mulai dibangun dan restaurant atau warung makan mulai bertambah jumlahnya. Serta pada atraksi pantai yang dulunya hanya untuk berfoto dan surfing saat ini digunakan untuk kegiatan lain dan untuk atraksi tebing yang dulunya tidak digunakan saat ini digunakan untuk foto prewedding bagi wisatawan mancanegara. Sedangkan untuk pengaruh perkembangan pariwisata terhadap prasarana pariwisata terkait dengan jalan, jalan yang ada dibenahi menjadi tangga dan paping. Terkait dengan persediaan air, Pantai Balangan mengambil air dari Desa Cengiling. Dan untuk tempat pembuangan samapah, di Pantai Balangan sampah - sampahnya dibuang di sempadan pantai yang kemudian dibakar.

\subsection{Saran}

Berdasarkan hasil dan pembahasan yang telah diuraikan sebelumnya, maka saran yang dapat diberikan yaitu pihak stakeholder khususnya masyarakat dalam kegiatan kepariwisataan diharapkan lebih memperhatikan kondisi lingkungan fisik seperti dalam pengeloaan sampah maupun membangun fasilitas pariwisata. Selain itu diperlukan fasilitas tambahan seperti tempat sampah untuk mengelola sampah organik dan non-organik. Sedangkan dalam membangun fasilitas pariwisata khusunya di pesisir pantai, masyarakat diharapkan lebih waspada karena ombak di Pantai Balangan cukup besar sehingga dapat merusak bangunan apalagi bangunannya semi - permanen.

\section{DAFTAR PUSTAKA}

Anonim. 2009. Undang - Undang Republik Indonesia Nomor 10 Tahun 2009 tentang Kepariwisataan.

Batafor, Edel M.D. 2016. Persepsi Wisatawan Terhadap Potensi dan Sarana Prasarana Wisata di Kampung Nelayan Tradisional Desa Lamalera Kabupaten Lembata Provinsi Nusa Tenggara Timur. Skripsi. Fakultas Pariwisata Universitas Udayana.

Butler, R. W. 1980. The Concept of a Toourism Area Life Cycle of Evolution: Implicationa for Management of Resources. Thr Carabian Geographer 24 (1) p.8.

Buttler, Richard and Douglas G. Pearce. 2003. Tourism Development: Routledge Advances in Tourism. United Kingdom: Routledges.

Faizun, Moh. 2009. Dampak Perkembangan Kawasan Wisata Pantai Kartini Terhadap Masyarakat Setempat di Kabupaten Jepara. Tesis Megister Teknik Pembangunan Wilayah dan Kota Universitas Diponegoro.

Gunarsa, I Nyoman. 2016. Respon Masyarakat Lokal Terhadap Perkembangan Pariwisata di Kelurahan Seminyak, Kecamatan Kuta, Kabupaten Badung, Provinsi Bali. Skripsi. Fakultas Pariwisata Universitas Udayana.

Lestyono, Renna. 2010. Dampak Negatif Perkembangan Pariwisata Terhadap Lingkungan Fisik Pesisir, Studi Kasus: Pantai Pangandaran. Jurnal Perencanaan Wilayah dan Kota Vol. 2 No. 2.

Poerwadarminta, W. J.S. 2002. Kamus Besar Bahasa Indonesia. Jakarta: Balai Pustaka.

Sunarta, I Nyoman. 2015. Study on the Development of Water Crisis in Bali Island in 2009 and 2013. Jurnal Pariwisata Vol. 2 No. 2. 
Vol. 6 No 1, 2018

2014. Dampak Perkembangan Usaha Akomodasi Terhadap Sumber Daya Air di Kecamatan Kuta Utara Kabupaten Badung Bali. Jurnal Pariwisata Vol. 1 No. 2.

Susilo, Fathul Huda Nur. 2015. Pengaruh Sektor Pariwisata Terhadap Penyerapan Tenaga Kerja di Kecamatan Bandungan, Kabupaten Semarang. Skripsi. Fakultas Ekonomikan dan Bisnis Universitas Diponegoro.

Suwena, I. K. 2010. Pengetahuan Dasar Ilmu Pariwisata. Denpasar: Udayana Press. 